\title{
NATURAL CONDITIONS FOR THE SEA SALT PRODUCTION IN BRAZIL
}

DINIZ, Marco Túlio Mendonça; ${ }^{a *}$ VASCONCELOS, Fabio Perdigão ${ }^{b}$

(a) Dsc. in Geography, Lecteur University Federal do Rio Grande do Norte (UFRN). http://lattes.cnpq.br/3075753552167640

(b) Dr. em Oceanography, Lecteur University Ceará (UECE). http://lattes.cnpq.br/2358953760401618

\section{(*) CORRESPONDING AUTHOR}

Address: UFRN, Av. José Evaristo, s/n, CEP: entro, Belo Horizonte - MG, Brasil. CEP: 59300000 - Caicó (RN), Brasil. Tel: (+55 84) 34214870 E-mail: tuliogeografia@gmail.com

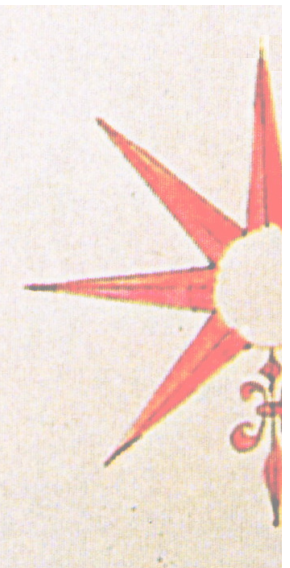

\begin{abstract}
Rio Grande do Norte and Ceará stand out among the largest producers of sea salt in Brazil. The entire production of Rio Grande do Norte and much of the production of sea salt of Ceará come from a stretch of concave coastline in relation to the Atlantic called Concave Excerpt of semiarid Brazilian East Coast. This section presents climatic characteristics providing increased productivity to salt activity. This study presents data from the natural dynamic of constraints that influence the productive potential of a salt-development. After analysis, it was found that the areas of fluvial-marine plains of Mossoró and Açu rivers and tidal flat in Galinhos-Guamare are those with the highest potential for production of sea salt in Brazil. The great vocation of these areas for the production of sea salt is due to the following factors: the soils are less permeable; the longshore transport of sediments and also the siltation of estuaries by the dunes are not important; natural water salinity is higher due to its greater confinement on the continent; and being larger the deposit of sediments of silt and clay fractions.
\end{abstract}

Keywords: Sea salt; Semiarid Brazilian Coast, Natural Conditions.

\section{RESUMO/ RESUMEN}

\section{CONDICIONANTES NATURAIS À PRODUÇÃO DE SAL MARINHO NO BRASIL}

A costa semiárida do Rio Grande do Norte e do Ceará se destacam entre os maiores produtores de sal marinho do Brasil. A totalidade da produção do primeiro estado e grande parte da produção do segundo é oriunda de um trecho de linha de costa côncavo em relação ao Atlântico, denominado Costa Branca da Costa Semiárida Brasileira. Este trecho apresenta características climáticas a conferir maior produtividade à atividade salineira. Neste trabalho analisam-se dados da dinâmica natural dos condicionantes a influenciar no potencial produtivo do empreendimento salineiro. Nele se constatou que as áreas das planícies flúvio-marinhas dos rios Mossoró e Açu e da planície de maré de Galinhos-Guamaré apresentam maior potencial para produção de sal marinho do Brasil e posto: os solos serem menos permeáveis; o transporte longitudinal de sedimentos e também o assoreamento dos estuários por parte das dunas móveis ser diminuto; a salinidade natural da água ser mais elevada devido ao maior confinamento dela no continente; e maior a deposição de sedimentos das frações silte e argila.

Palavras-chave: Sal marinho; Costa Semiárida Brasileira; Condicionantes Naturais.

RESTRICTIONS NATUREL POUR LA PRODUCTION DE SEL DE MER AU BRESIL

Rio Grande do Norte et Ceará se distinguent parmi les plus grands producteurs de sel de mer au Brésil. Toute la production du Rio Grande do Norte et grande partie de la production de sel de mer du Ceará sont originaires d'une étendue de côte concave par rapport à l'Océan Atlantic nommée Morceau Concave Est de la Côte Semi-Aride du Nord-Est du Brésil. Cette partie présente des caractéristiques climatiques qui accordent une plus grande productivité a l'activité salinière. Cette étude analyse la dynamique naturelle des conditions qui portent influence sur le potentiel de production de sel. Suite aux analyses, il a été constaté que les zones de plaines fluviales-marines de rivières Mossoró et Açu et l'estuaire-estran de Galinhos-Guamaré sont ceux qui ont présenté le plus grand potentiel pour la production de sel de mer au Brésil. La grande vocation de ces zones pour la production de sel de mer se doit aux facteurs suivants : les sols sont moins perméables; le transport des sédiments longitudinaux est moins important; les estuaires sons moins ensables par les dunes; la salinité de l'eau de mer est plus élevée en raison d'un plus grand confinement sur le continent; et les basins sont plus envasés par les fractions fines composés de silt et argile.

Mots clés: Sel de mer, Côte Semi-Aride du Brésil, Restrictions Naturels. 


\section{INTRODUCTION}

The states of Rio Grande do Norte and Ceará stand out among the largest sea salt producers in Brazil. The total production of Rio Grande do Norte and much of the sea salt production of Ceará come from a stretch of concave coastline in relation to the Atlantic called Costa Branca of semiarid Brazilian East Coast. This division was made by Diniz and Oliveira (2016), who, when studying the dynamics of the area, proposed a new division for two of the macro-compartments of the Brazilian coast proposed by Muehe (2006). North Semiarid Coast and South Semiarid Coast macro-compartments were grouped into a single one called semiarid Brazilian Coast (CSB, that goes from Golfão Maranhense to Cabo do Calcanhar / RN), which was subdivided based on the atmosphere-earth-ocean interaction into three stretches, among them Costa Branca (which goes from Icapuí / CE to Cabo do Calcanhar / RN) of CSB. The other macro-compartments proposed by Diniz and Oliveira (2016) are Costa das Dunas (from Icapuí / CE to the mouth of the Acaraú River / CE) and Costa dos Deltas (from the mouth of the Acaraú River to Golfão do Maranhão).

After analyzing the climatic conditions of sea salt producers in the Brazilian coastline, Diniz (2013) pointed out a great advantage in terms of potentials for the extraction of sea salt in the Costa Branca and adjacent areas (Plains of Pirangi and Jaguaribe Rivers), also called Costa do Sal. In this area, the climate is hot and dry semiarid, with considerable deficit between precipitation and evaporation. Empirically, after centuries of salt extraction activity in Brazil, the great capital perceived this greater potential of the Costa Branca, where resources for the modernization of the activity were invested. Currently, the region produces more than $95 \%$ of Brazilian sea salt. In the year 2014, 6,050,000 tons of sea salt were produced in Brazil, 95\% in Rio Grande do Norte and another 1.5\% in Ceará (DNPM, 2015).

The producing areas (or with potential for production) of sea salt on the Costa Branca are the fluvial-marine plains or tidal plains located in estuarine areas of river valleys or as deltas. In the Geomorphology map of the area, it can be observed that there are two fluvial-marine plains on the coast of Ceará: the Jaguaribe River and the Pirangi River, with no salt production (or no production has been recorded); there is still a tidal plain in Icapuí, producing almost half of the total sea salt produced in Ceará.

In the same map, it is possible to observe that there are three other areas with sea salt production potential for in Rio Grande do Norte: two in fluvial-marine plains of Apodi-Mossoró and Piranhas-Açu Rivers; and the third area is located on a tidal plain between Municipalities of Galinhos and Guamaré. In the year 2014, these areas of the coast of Rio Grande do Norte accounted for approximately $95 \%$ of Brazil's sea salt production, compared to only $1.5 \%$ in the entire coast of Ceará (DNPM, 2015). In this work, we present other natural conditions that explain the great difference in sea salt production in areas so close, for which the climatic conditions are similar. Diniz (2013) identified that these areas have similar climatic characteristics, so climatic conditions were excluded from this analysis. However, before discussing the local dynamics and the natural potential of each area for sea salt production, we will present some assumptions for the understanding of this text.

\section{THEORETICAL ASSUMPTIONS FOR UNDERSTANDING THE NATURAL DYNAMICS OF THE EASTERN CONCAVE STRETCH OF THE SEMIARID BRAZILIAN COAST}

In the Geomorphology Map of the area (Figure 1), it is possible to observe that the coastal plain (Ad) is more extensive in the stretches of the coast that are in the geometric form approximately in 


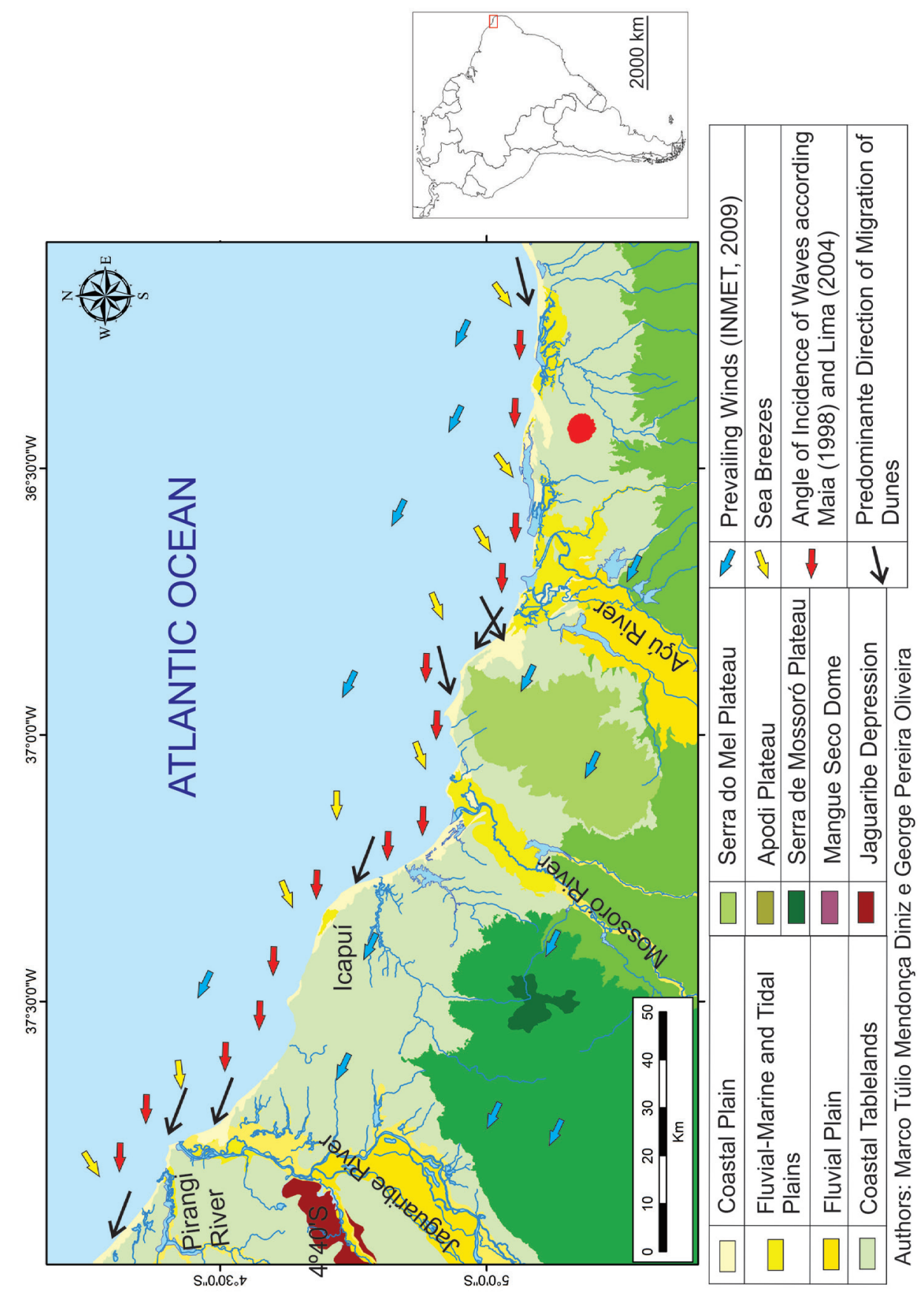

Figure 1 - Geomorphology map of Costa Branca or Costa do Sal and surroundings.

an NW-SE direction, because in this conformation, the coastline is approximately perpendicular to NE and E winds (sea breeze), which, according to Diniz (2013), are more intense and have a greater capacity to transport sediment from the shoreline to the interior of the continent. Similarly, when the coastline has this conformation (NW-SE), the loss of wind sediments from dunes to beaches by the prevailing winds of the area, the SE trade winds, is lower.

Conversely, when the coast assumes W-E or even WSW-ENE conformation, the sediment transport capacity is reduced by the Northeast, and mainly Eastern winds, since the coast is almost parallel to the action of these winds, which are the winds with the greatest potential to transport sediments to the inner continent, as well as the ability of the Southeastern trade winds to erode the dunes and to deposit wind sediments again on the shallow platform (Figure 1). This fact influences the potential for sea salt production, since the deposition of wind sediments in fluvial-marine (or 
tidal) plain areas is responsible for increasing soil drainage, since these sandy sediments contribute to soil permeability.

Another important characteristic is also explained by the coastal geometry, since it is known that

[...] direction, velocity and volume of sediment transport parallel to the beach, both in the surf zone and on the beach, also called the coastal drift, depend on the obliquity of wave incidence, that is, the angle formed between the wave crest, on the surf zone, and the beach line. With angles greater than $5^{\circ}$, the longitudinal stream speed is quite efficient. (MUEHE, 2008, p.271).

The efficiency of transporting sediments in the longitudinal and coastal drift streams is minimal at incidence angles $0^{\circ}$ and maximum at $45^{\circ}$ and returns to minimum at $90^{\circ}$, as shown in the graph of Machado (2007).

The velocity of the longitudinal stream $(\mathrm{m} / \mathrm{s})$ can be measured by the Longuet-Higgins equation (1970, apud MUEHE, 2008):

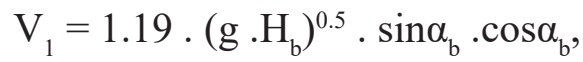

Where, according to Borba (1999):

$\mathrm{V}_{1}=$ the average speed of the longitudinal stream $(\mathrm{m} / \mathrm{s})$;

$1.19=$ experimental constant;

$\mathrm{g}=$ gravity acceleration $\left(9.81 \mathrm{~m} / \mathrm{s}^{2}\right)$;

$\mathrm{H}_{\mathrm{b}}=$ mean significant wave height in the surf zone $(\mathrm{m})$; and

$\alpha_{b}=$ incidence angle of waves (in degrees).

Considering also that the sand volume daily transported can be estimated through the equation established by Komar (1983 apud MUEHE, 2008):

$\mathrm{Q}_{\mathrm{S}}=3.4 \cdot\left(\mathrm{E} \cdot \mathrm{C}_{\mathrm{n}}\right) \mathrm{b} \cdot \sin \alpha_{\mathrm{b}} \cdot \cos \alpha_{\mathrm{b}}$,

Where according to Borba (1999):

$\mathrm{Q}_{\mathrm{S}}=$ estimated sand volume daily transported $\left(\mathrm{m}^{3} /\right.$ day);

$3.4=$ experimental constant;

$\mathrm{E}=$ wave energy (joules $/ \mathrm{m}^{2}$ ); and

$\mathrm{C}_{\mathrm{n}}=$ speed of the wave group or celerity $(\mathrm{m} / \mathrm{s})$.

Given that the product between $\sin \alpha_{b} \cdot \cos \alpha_{b}$ is larger at angles of $45^{\circ}$, near this incidence angle of waves in relation to the coastline will be greater the speed and volume of sediments transported by the longitudinal stream and the coastal drift at angles of $0^{\circ}$ and $90^{\circ}$ the product between $\sin \alpha_{b}$. $\cos \alpha_{b}$ equal to zero, which cancels the longitudinal transport. In the case of CSB, sediment transport will be more efficient in areas where the coastline is in the NW-SE direction, and will have lower velocity and volume transported in the W-E and WSW-ENE directions, since, according to Maia (1998), in this area, waves come mainly from ESE, forming a more favorable angle to the velocity of the longitudinal stream and the transport of sediments in the area, which runs from the mouth of the Jaguaribe River to the mouth of the Acaraú River, on the coast of Ceará. Conversely, between the mouth of the Apodi-Mossoró River (RN) and the Cabo do Calcanhar (RN), the longitudinal stream velocity and sediment transport volume are minimal for most of the year, since in these areas, the incidence angle of waves is close to zero. Between the mouth of the Jaguaribe (CE) and the Apodi-Mossoró Rivers (RN), the coastline geometry abruptly alternates in Icapuí (CE), where it forms an angle of about $70^{\circ}$, shifting from SSE-NNW to E-W direction. The processes described in this subtitle that are operative in TCL can be visualized in figure 1.

After these considerations, the potentialities for sea salt production in the fluvial-marine and tidal lowlands of the Eastern Concave Stretch of the Semiarid Brazilian Coast will be analyzed. 


\section{THE FLUVIAL-MARINE PLAIN OF THE PIRANGI RIVER}

The area of the fluvial-marine plain of the Pirangi River was calculated in about $14.94 \mathrm{~km}^{2}$, and the area is composed of fluvial-marine sediments of the Holocene age. The plain is adjacent to the Costa Branca and has a narrow area, where its muddy sediments cover a river channel area drowned by marine transgression flanked by the coastal tablelands (Figure 1), composed of Neogeneian sandstones of the Barreiras Formation (SOUZA, 2000; CARVALHO et al., 2003).

This plain is located in a small hydrographic basin with $4,374 \mathrm{Km}^{2}$ in area, which together with others the group called Metropolitan Hydrographic Basins of Fortaleza. Its spring occurs in crystalline terrains in lowlands about 200 m northeast of the municipality of Quixadá / CE, and in about $80 \%$ of its thalweg, the average slope is $0.05 \%$, forming many ponds in its course. There are no significant tributaries and their annual average flow was estimated at only $1.1 \mathrm{~m}^{3} / \mathrm{s}$ (FUNCEME; UECE, 2007).

Its mouth is deflected to the left by a small spit, given its small flow, which breaks the parallel drainage pattern of its low course. These characteristics of small flow and small slope cause the river to deposit only fine sediments in the estuarine area. In the study that Larach, Pötter and Azevedo (1974, p.58) conducted in the region, Solonchak Solonetzico (now Salic Gleysols) were found imperfectly drained composed of $35 \%$ of silts and $59 \%$ of clays; plus $4 \%$ fine sand and only $2 \%$ coarse sand in its fluvial-marine plain. The sand fraction would come from wind, which is very small, since the encounter of the Pirangi River with the sea occurs in a stretch where the coast assumes an approximately W-E conformation. In these areas, the longitudinal transport of sediments is minimal, which allows a greater deposition of sediments, fluvial contribution, and ocean basins. The greater presence of silt and clay sediments contributes to lower soil drainage, which favors saline activity.

According to a report by FUNCEME and UECE (2007), the salinity of this area reached $36.4 \mathrm{~g}$ of salt per $\mathrm{kg}$ of water mass in the ebb cycle and $36.1 \mathrm{~g}$ in the flood cycle, both during the dry season. However, salinity reaches the minimum values of 0.5 in stations farthest from the ocean, which reflects a considerable contribution of continental waters to the estuary, even in the dry season. Salinity near the adjacent ocean, around 36.0, only manifests in areas near the mouth. This estuary can be considered from euhaline 1 (salinity between 40 and 30) to mixohaline (salinity between 18 and 30), depending on the section, with increasing salinity downstream.

The area has potential for sea salt production, mainly due to its climatic characteristics, the proximity of the Fortaleza consumer market, the excellent road access and the natural impermeability of mangrove soils, mainly composed by fine fraction sediments, including the presence of sediments brought by the tide to the estuary (FUNCEME, UECE, 2007, SEMACE, 2004). The amount of wind sands in the area close to the fluvial-marine plain is small, since the coastal plain is very narrow due to the approximately W-E coast conformation, near the mouth of the Pirangi River, which limits the capacity of sea breezes (NE and E) to construct a dune field that could silt up the estuarine area (Figure 2).

The main limitation to the saline activity in the fluvial-marine plain of the Pirangi River lies in its small area, which makes the implementation of large mechanized saline companies difficult. The area has more potential to shrimp farming, as this activity uses smaller tanks and predominates in the area. 


\section{THE FLUVIAL-MARINE PLAIN OF THE JAGUARIBE RIVER}

The Jaguaribe River is the largest river of intermittent regime of Brazil, extending for about $610 \mathrm{~km}$ from southern to northeastern state of Ceará. Its watershed occupies more than $50 \%$ of the state's territory (IBGE, 1999) and its main course is dominated by faults, mainly the Jaguaribe Fault, which extends from southern to northeastern Ceará in the SW-NE direction (MAIA, CLAUDINO SALES and PEULVAST, 2006).

The eastern part of the Jaguaribe Basin in its mid and low course drains and dissects the western edge of the Potiguar Basin, considering the predominance of dry climates from the Cretaceous in the Brazilian Northeastern region (PEULVAST, CLAUDINO-SALES, 2006). The process of lateral degradation of the western edge of the Potiguar Basin by the Jaguaribe River has occurred slowly and continuously over a long period of time, possibly since the beginning of the Neogene (CARVALHO NETA, 2007).

The process described above is responsible for modeling the cuestiform relief of the Chapada do Apodi, a feature present on the western edge of the Potiguar Basin. This sedimentary basin demarcates the eastern part of the Jaguaribe basin from the middle to its lower course. In the vicinities of the city of Jaguaruana, the Jaguaribe River no longer presents the SW-NE direction and starts to have a predominant $\mathrm{S}-\mathrm{N}$ direction, deviated by an elevation in the Barreiras Formation. During the Holocene, its mouth was displaced to the northwestern direction due to the strong longitudinal sedimentary transport on the coast, which has SE-NW conformation (Figure 2) and the large dune field that forms east of the present mouth. This dune field begins near the Canoa Quebrada village, where the Jaguaribe mouth had been located at some point in the Holocene, a fact confirmed by the presence of a line of beachrocks in Canoa Quebrada (MAIA, 1993). Since the regression that began at $5.1 \mathrm{ka}$, the mouth of the Jaguaribe River has migrated to the northwestern direction (MAIA, 1993).

The low Jaguaribe River is the catchment of the defluvium of its considerable watershed that drains more than half of Ceará (CARVALHO NETA, 2007), with a solid discharge of the order of 43,770 $\mathrm{t}$ / year, values calculated in the 1999-2000 period by Cavalcante (2001), which should make its fluvial-marine plain wider than its upstream fluvial plain. This would occur if there were depressed and more flat lands near its current mouth, which does not occur, since in its downstream portion, the Jaguaribe River has carved a fluvial cliff in rocks of the Barreiras Formation in its western margin, where practically there are no plains (Figure 2). Its fluvial-marine plain is somewhat more extensive at the eastern portion of the river bed, but this has been silted up by the dunes field positioned immediately to the east of the Jaguarian fluvial-marine plain.

A little further upstream of this area, but still in the lower Jaguaribe, the river plain is wider, forming a wide terrace that was formed at the time of the maximum marine transgression of the Holocene (MAIA, 1993). According to Suguio et al. (1985), this transgression occurred at about $5.1 \mathrm{kA}$ A.P., when sea level reached about $5 \mathrm{~m}$ in relation to its current level. This plain is wider at east of the river bed and extends to altitudes of $5 \mathrm{~m}$ near Itaiçaba (MAIA, 1993). Part of it is of fluvial-marine influence and only part of it is fluvial (Figure 1).

For its most part, the Jaguaribe basin bathes crystalline terrains, except at east of its mid-low course, where Açu Sandstone and Jandaira Limestone (Potiguar Basin) sediments are dissected. In the fluvial-marine plain of the Jaguaribe River, there is strong deposition of wind sediments of the sand fraction. This silting is due to the position of the estuarine area to leeward of the bypass direction of dunes or migration of wind sediments, which occurs in E-W and SE-NW directions. The strong longitudinal transport of sediments from the coast in this area is also responsible for taking much of the suspended material brought by the river towards the estuary.

As a result, the particle size of sediments of this plain tends to be larger. In a study carried out by Godoy (2011), sediments were collected at three points (testimony) along the Jaguaribe estua- 
rine plain. Silt and clay fractions were predominantly found (80\%) only in the first $20 \mathrm{~cm}$ of soil from the nearest part of the river mouth, where the plain is narrower and where there is deposition of sediments. The deposition of these oceanic sediments has predominated in the area, since much of the solid fluvial load of the Jaguaribe River has been dammed in its several dams. Still in this sample (testimonial 06 of GODOY, 2011) from $20 \mathrm{~cm}$ of soil, there is a $35 \%$ occurrence of coarse sand. At the other points of the estuarine plain, the superficial occurrence of silt and clay reaches only $60 \%$ and $50 \%$, the latter occurring in the sample furthest from the mouth. The study by Godoy (2011) shows the weak presence of silt and clay fractions in the estuarine area of the Jaguaribe River, which leads to a greater soil permeability and drainage, factors that have influenced the decrease of saline activity productivity.

According to Dias (2007), since 1990, there has been a strong decrease in the Jaguaribe River flow, mainly due to the growth in human demand for fresh water. According to data from the National Water Agency (ANA, 2006) between 1978 and 1989, in its estuary, the river presented flow peaks of more than $2,250 \mathrm{~m}^{3} / \mathrm{s}$. From 1990 to 2006, these peaks did not exceed $251.3 \mathrm{~m}^{3} / \mathrm{s}$, a reduction of more than ten times in peaks due to the control of its flow through the dams. In the latter period, the average flow rate was $24.5 \mathrm{~m}^{3} / \mathrm{s}$, still considered high in relation to the regional standard, mainly when compared to the average Pirangi river flow of only $1.1 \mathrm{~m}^{3} / \mathrm{s}$.

According to Marins et al. (2003), salinity in the Jaguaribe estuary is slightly higher than that of the ocean, ranging from 36.5 to 39.1 grams of salt per kilogram of water, similar to what occurs in some rivers in the region. Currently, salinity tends to grow from the mouth to the interior, as the confinement of waters increases. This salinity is higher than 39.0 in Aracati, located about $15 \mathrm{~km}$ away from the mouth and is over 36 in the community of Cabreiro, located about $22 \mathrm{~km}$ away from the mouth. Saline waters advance until they are dammed by a dike, in the form of a wet passage, in Itaiçaba, where even with the contribution of a small fresh water flow, salinity reaches 29.4, and this estuary can be classified as Euhalin, with rising salinity upstream in its low course.

The area of the fluvial-marine plain of the Jaguaribe River is little favorable to sea salt production because although it has an area of $64.63 \mathrm{~km}^{2}$, it is narrow and has soils with drainage greater than that recommended for saline activity in most of this area. In years of great floods, there is a significant increase in the fresh water flow, a fact that would harm the activity. These characteristics were empirically perceived by the local inhabitants, since there are no historical records of saline activity in the largest fluvial-marine plain of Ceará.

\section{THE TIDAL PLAIN OF THE ICAPUÍ RIVER}

The tidal plain of Icapuí has only $8.26 \mathrm{~km}^{2}$, the smallest of the areas analyzed in this research. The plain is within a flood tide delta that deposits sediments that mix with sediments brought by waters exulted by cliffs (MEIRELES; SANTOS, 2011). The dynamics of the area is strongly dominated by tides, since the contribution of fresh water to the estuarine system is seasonal and exclusively phreatic.

Meireles, Raventos and Thiers (2006) state that the existing tidal channel has estuarine characteristics, as it mixes fresh water from the surface stream and outcrops of subsurface water. The form of this plain is subatual and has been formed since the last Holocene transgression, at about $5.1 \mathrm{ka}$, having passed through lagoon and delta phases, according to trans-regressive movements of the coastline. Each of these phases has own sedimentation characteristics, sometimes with marine predominance, sometimes continental.

According to Meireles, Raventos and Thiers (2006), there is a predominance of sandy materials in the sedimentation, followed by clayey-silt materials, organic matter and biodetrites, which corroborates the study by Larach, Pötter and Azevedo (1974), which among three soil samples collected in the area, there was a predominance of fine sand in two of them $(63 \%$ and $74 \%)$, and silt and clays 
in another sample (54\%); however, Salic Gleysols were considered to be poorly drained. Perhaps the presence of organic material, such as algae for example, has contributed to poor drainage. The authors also reported that the predominance of sandy material occurs in the vicinity of the high tide line, which is due to the longitudinal flow of sediments near the coastline.

The coastline of the area is positioned almost parallel to the equator. The plain is formed at the rear of spits, forming small restinga forests, which according to Meireles, Raventos and Thiers (2006), are formed by the flow of the E-W longitudinal stream (Figure 2). According to the same authors, there are three generations of dunes in the surroundings, which are especially found to the east of the area where the coastline has SSE-NNW direction. The dune field to the east is also responsible for silting up the tidal plain area with sediments of the sand fraction.

Once again, the geometric conformation of the coastline is remarkable, as due to its EW position, there is a tidal plain in an area that could be a simple recess on the coast, if not for the presence of restinga forests formed by the damming the waters by spits. These formations only occur in the CBS in areas where the longitudinal sedimentary flow is smaller and where more intense winds reach the coast in a subparallel way, that is, where the coastline has approximately E-W conformation. In these areas, the sedimentary flow is small, which provides sedimentary deposition in the form of sandy banks, barrier islands, spurs, spits or restinga forests. In the other areas with shoreline conformation approximately SE-NW, the strong longitudinal sedimentary flow does not allow sufficient deposition for the formation of barrier islands. In these areas, the coastal plain tends to be wider, which makes the coastline more rectilinear by covering its imperfections (recesses) through wind sedimentation.

The greatest potential of the Icapuí tidal plain for sea salt production is due to the climate, to the poor drainage of soils and to the proximity to the Areia Branca Port-Island that facilitates the production runoff. The biggest limitation for saline activity is that it is a very small area, yet this is the main area for sea salt production in Ceará.

\section{THE FLUVIAL-MARINE PLAIN OF THE APODI- MOSSORÓ RIVER}

To understand the current shape of this plain, it is of fundamental importance to keep in mind some geological processes of the evolution of the Potiguar Marginal Sedimentary Basin, which has several faults that have been reactivated in the Cenozoic and that command diverse forms of relief such as river, valleys and some sedimentary plateaus that function as watershed in the context of the sedimentary basin.

Through geoelectric drilling, Maia (2012) identified that at the boundary of the Cretaceous-Neogene contact, that is, from the top of the Jandaíra formation to the base of the Barreiras formation, Serra do Mel is located at $200 \mathrm{~m}$, reaching $270 \mathrm{~m}$ of altitude. In the surroundings of the Serra do Mel, this contact does not exceed the quota of $120 \mathrm{~m}$, sometimes located at sea level or below that, in the coast and in the fluvial-marine plain of the Mossoró River. The author suggests that there was a tectonic inversion in the Potiguar basin, with a current tectonic compression regime in the NW-SE direction that has reactivated faults and is responsible for a dome elevation (Serra do $\mathrm{Mel}$ ) and for tectonic depressions, as in the case of the low Mossoró River valley. These grabens and horsts are oriented in the NE-SW direction.

The radial type drainage in the Serra do Mel dome elevation (anticlinal) disperses small channels, being a watershed for the fluvial-marine plains of the Mossoró and Açu Rivers (MAIA; BEZERRA, 2013).

Besides neotectonics, eustasia would have participated in the widening of the Mossoró River valley above the Potiguar Basin. Maia and Bezerra (2013) reported that after the lowering of the general base level at the last glacial apex (between 20 and $18 \mathrm{ka} \mathrm{AP),} \mathrm{there} \mathrm{was} \mathrm{dissection} \mathrm{and}$ 
deepening of the river valley, which was certainly submerged in the holocene transgression (5.1 ka AP) and currently houses the broad fluvial-marine plain of the Mossoró River. This area would therefore be a wide depression formed by endogenous and exogenous factors between the Neogene and the Quaternary.

This fluvial-marine plain has $197.87 \mathrm{~km}^{2}$, it is a tectonic depression that is being filled by sediments and that is about $8 \mathrm{~km}$ wide by $30 \mathrm{~km}$ long. According to Maia and Bezerra (2013), the $0 \mathrm{~m}$ altitude quota is $30 \mathrm{~km}$ away from the coastline, a fact that can be verified in SRTM images. The flow of this river is controlled by the Apodi dam, which is $110 \mathrm{~km}$ upstream of the mouth, in addition, the escarpment in the contact between the crystalline and the Apodi Plateau diminishes the competence of the fluvial canal (MAIA, BEZERRA, 2013), which associated with low altimetric heights favor seawater penetration of about $30 \mathrm{~km}$ in the continent, near the city of Mossoró, and according to SEMARH / RN (1998), the mean river flow rate is $17.60 \mathrm{~m}^{3} / \mathrm{s}$.

According to Silva, Miranda and Silva (2004), this is a hypersaline estuary, with negligible influence of river discharge, given its vast spatial extent in relation to the average flow. In the measurements made by the authors, the salinity varied between 39.68 and 49.30 grams of salt per kilogram of water, being higher in collection stations 2 and 3 (around $5^{\circ} \mathrm{S}$ ) about 5 to $7 \mathrm{~km}$ distant from the coastline, and shorter at the station closest to the ocean and in furthest away from it. The authors reported that the high salinity observed in stations 2 and 3 may be a reflection of the prominent saline activity in the area.

It is a fact that the salinity value is greater than that of the adjacent ocean, due to the confinement of oceanic waters in a vast plain that penetrates for many kilometers in the continent. In it, the confined water is submitted to atmospheric action in an area of high potential evaporation (1985.5 mm / year, INMET, 2009), which tends to raise the salinity of waters in intermediate areas between the fresh water source and the ocean. This area is located approximately in the center of the fluvial-marine plain, exactly where there is higher sea salt production. Salinity generally grows upstream to about $7 \mathrm{~km}$ from the mouth and then tends to decrease slightly, but the salinity is greater than that of the ocean up to about $20 \mathrm{~km}$ away from the mouth, and can be classified as hypersaline (salinity>40).

Larach, Pötter and Azevedo (1974) collected soil samples in 11 sea salt plants of the region, in all of them, the soil was considered poorly drained or imperfectly drained, with predominance of silt and clay fractions in the fine soil samples. The proportion reached $78 \%$ of clay and $20 \%$ of silt in Salic Gleysols of Francisco Menescal sea salt plant in Mossoró (LARACH; PÖTTER; AZEVEDO, 1974, p.27). The inexpressive flow and drainage of the Apodi-Mossoró River are only capable of transporting suspended sediments to the estuary. The E-W position of the river mouth area is very unfavorable to the longitudinal transport of sediments and sedimentation by wind sands (Figure 2), which contributes to the scarcity of sediments of this size. The deposition of oceanic sediments is another element that contributes to the poor drainage of soils.

Most of the area, historically occupied by salt plants, has been and still is hypersaline plain or salons, according to Ab'Sáber (1977), colonized by apicuns or with complete absence of vegetation, areas known as salty. Figure 4 shows that there are still areas of hypersaline plain not occupied by the saline activity, which serve as testimony of the previous landscape, where saline waters of the estuary occupied vast areas in exceptional high tides and when the low tide formed several small shallow lagoons, which submitted to atmospheric action, evaporated, naturally leaving salt layers on the surface. These were the areas used by the saline industry. 


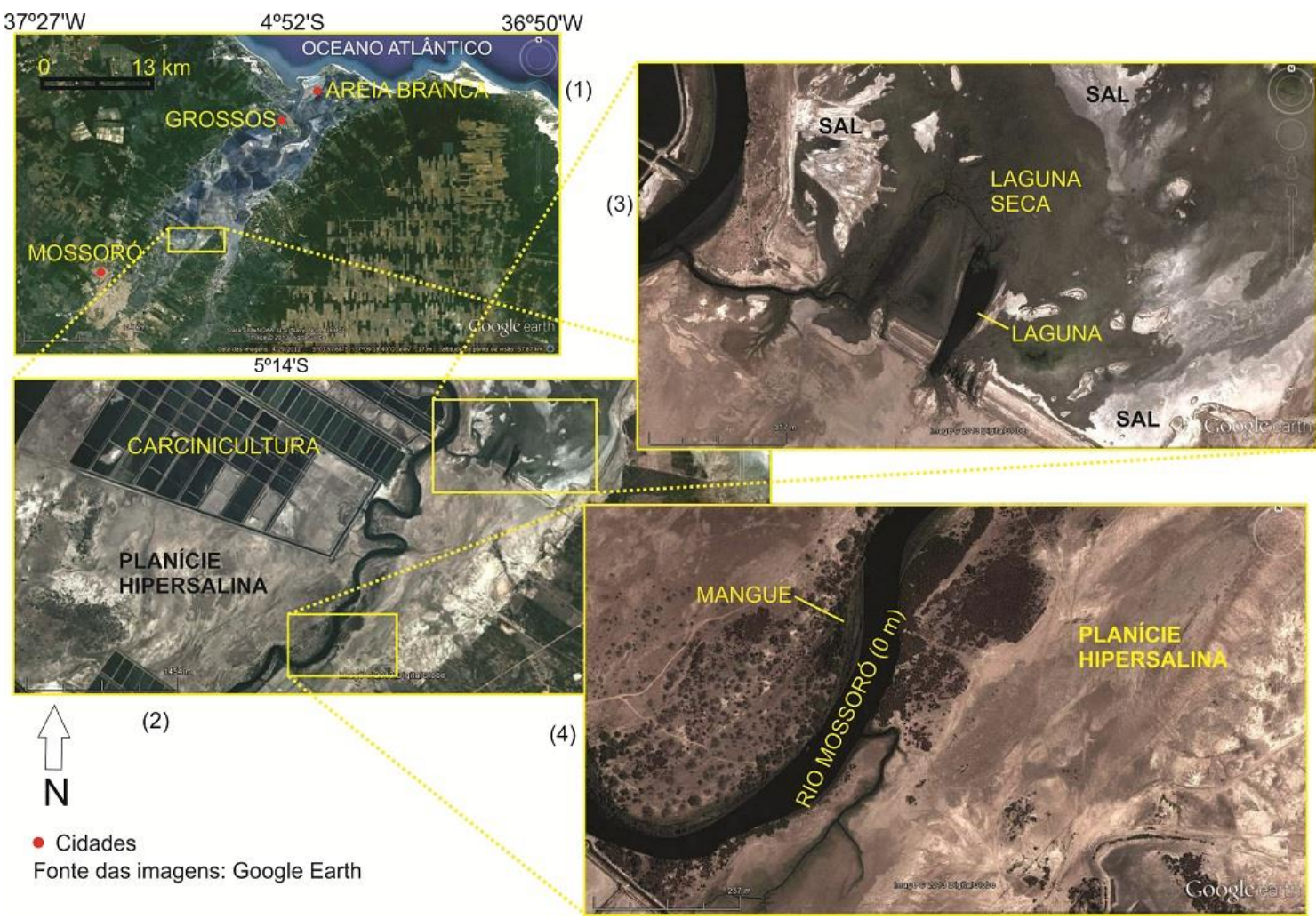

Figure 2 - Hypersaline Plain of the Mossoró River. Note the large extent of the area (1); presence of shrimp farm upstream of the estuary (2); presence of naturally precipitated salt (3); and the narrow mangrove along the river (4). Altitudes between 0 and $1 \mathrm{~m}$; distant area of about 23-25 km from the river mouth (municipality of Mossoró), where the presence of saline activity is lower. Source: Google Earth, images from 08/31/2012.

The area of the fluvial-marine plain of the Mossoró River territorially belongs to three sea salt producing municipalities: Mossoró, which produced in 2011 about 1500 thousand tons; Areia Branca, which produced 578 thousand tons; and Grossos, which produced 302 thousand tons (DNPM, 2012). The production of this area accounts for about $53 \%$ of the total $\mathrm{RN}$ and for about $49 \%$ of the total national production. The great natural potential, the proximity to the Areia Branca port and the commercial connections of the important city of Mossoro help to explain the predominance of this area in terms of sea salt production in the regional and national context.

\section{THE FLUVIAL-MARINE PLAIN OF THE PIRANHAS-AÇU RIVER}

Like the other two sea salt producing areas in Rio Grande do Norte, this plain is also inserted in the geological context of the Potiguar Meso-Cenozoic Sedimentary Basin.

The origin of the Potiguar Basin is linked to the evolution of the Atlantic equatorial margin, begun at the end of the Jurassic. The dextral differential rotation between South America and Africa around a pole located near the south of Ceará, generated in the Province of Borborema a regime of efforts with north-south distension and east-west compression, propitiating the development of several rift basins, as is the case of the Potiguar rift, under transtensional and transpressional regimes (FRANÇOLIN; SZATMARI, 1987, apud CALDAS, 1998).

According to Matos (1992), the Potiguar Basin was implanted on the rocks of the crystalline basement, taking advantage of its predominant trend of NE-SW direction during the Eocretaceous, being the Carnaubais Fault System the main system of the Potiguar Rift. On the other hand, Hackspacher \& Oliveira (1984) associated the Carnaubais Fault System to a possible reactivation of the Portalegre Shear Zone, which operated during the Brasiliano period (Moura-Lima et al., 2011, pp. 78-80). 
The direction of the fault system mentioned above commands several important forms of relief of the area such as the course of the Mossoró and Açu Rivers, and plateaus such as the Serra do Mel that has a general NE-SW direction. Another important fault system is that of Afonso Bezerra, with NW-SE direction. Moura-Lima et al. (2011) reported that this system would have been reactivated at the boundary between the Cretaceous and the Paleogene, but even quaternary sedimentary covers are affected by this reactivation. Maia and Bezerra (2013), in turn, reported that there is a quaternary reactivation of NE-SW and NW-SE fault systems in this portion of the Potiguar Basin.

The pair of Carnaubais (NE-SW orientation) and Afonso Bezerra (NW-SE orientation) fault systems are responsible for controlling several forms of relief on the Potiguar Northern Coast. These forms have been adapted to grabens, horts and domes among others resulting from epirogenetic manifestations. The geometry of the coast of Caiçara do Norte-RN is commanded by the Carnaubais Fault (CALDAS, 1998). The same appears to occur east of the Açu River delta to the Ponta do Mel (Areia Branca-RN), which seems to have the geometry of its coastline controlled by the Afonso Bezerra Fault.

Bezerra et al. (1998) proposed that the eastern portion of the Carnaubais Fault in this area has been submitted to uplifts in the last 5,000 years. To the west of this fault, there is a coast extremely low, where the quota $0 \mathrm{~m}$ advances $12 \mathrm{~km}$ inland, in an extension of more than $30 \mathrm{~km}$ of width. Bezerra, Barreto and Suguio (2003) concluded that between $5 \mathrm{ka}$ and $4.5 \mathrm{ka}$ before the present, the sea level was about 2.5 to $4 \mathrm{~m}$ above the current level in the Northern Potiguar coastline, which means that, as the Mossoró River estuary, the entire Açu Delta dates less than 4,500 years. Until this period, the area seems to have formed a shallow bay or even several lagoons separated by barrier islands, which are being silted by the river and tides. The coastline in this stretch is in progress. Since then, paleodunes positioned to the south of this fluvial-marine plain (Figure 1) are an important indicator of the existence of this paleobay.

The area of the fluvial-marine plain of the Piranhas-Açu River is $222.89 \mathrm{~km}^{2}$, unlike the estuary of the Mossoró River, which is deltaic, with at least three estuarine channels, and therefore is wider than longer when viewed in the map. It is more than $30 \mathrm{~km}$ wide and about $14 \mathrm{~km}$ long. It is an area with slope very close to zero. In a photograph taken on the banks of the BR-406 highway, it is almost impossible to verify imperfections in the relief to the horizon; the area is largely occupied by saline activity, where evaporating and crystallizing tanks dominate the landscape (Figure 3).

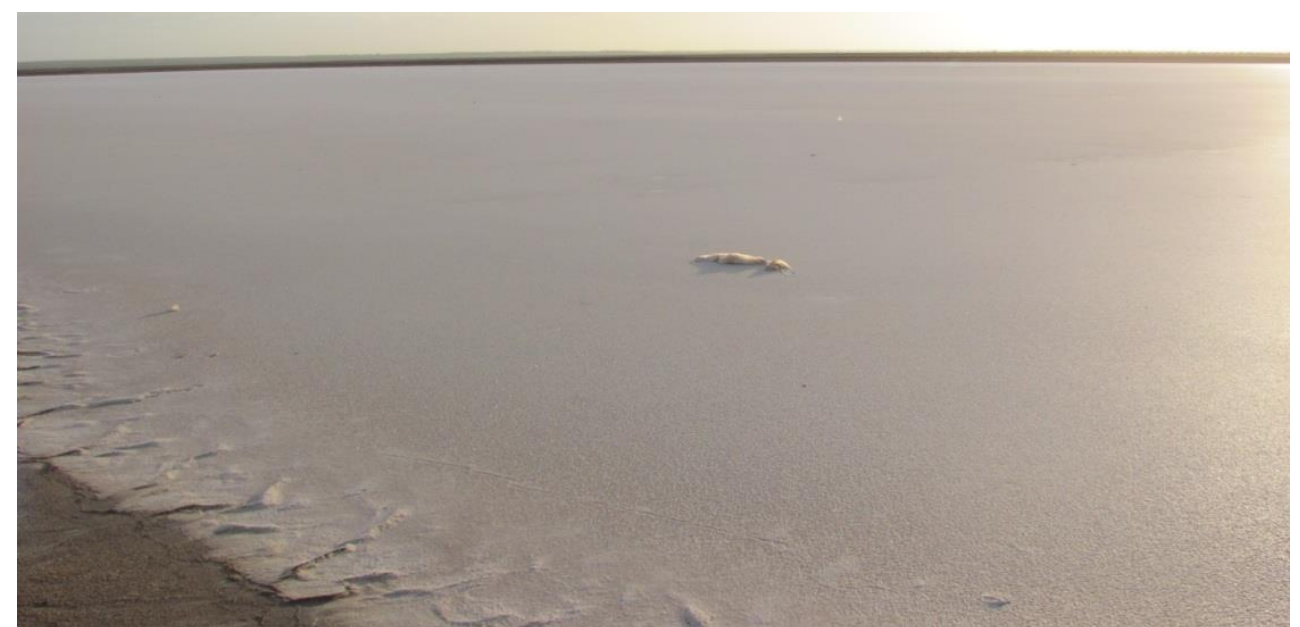

Figure 3 - Salt crystallizer in saline located on the BR-406 highway in the Municipality of Macau-RN. In the tank, it is possible to perceive a crystallized salt blade, to the horizon a extremely flat relief stands out, with almost no slope. In the lower left corner, the contact with the saline soil composed of clays of dark gray coloration. Photo taken by the authors on $04 / 29 / 2012$, even though it is one of the rainiest month, the clear sky and the strong incidence of the solar rays in the area are highlighted.

As in the Mossoró plain, salt plants implanted in this area took advantage mainly of hypersaline plains (Figure 4), practically devoid of mangroves and where salt naturally precipitated when 
salt waters were dammed in the lagoons, especially in syzygy tides (COSTA et al., 2013).

The average flow rate of the Piranhas-Açu River estimated by SEMARH / RN (1998) is 24.56 $\mathrm{m}^{3} / \mathrm{s}$ over crystalline lands. Currently, the regularized flow after the Armando Ribeiro Gonçalves Dam is 17 to $18 \mathrm{~m}^{3} / \mathrm{s}$ (CBH-PIANCÓ-PIRANHAS-AÇU, online). After this dam, the waters of the river enter the permeable sedimentary lands in the municipalities of Açu and Ipanguaçu and a large part of these waters is used in agriculture, with emphasis on the largest consumer, the Vale do Açu banana agribusiness. When reaching the fluvial-marine area, the contribution of fresh water is negligible.

Larach, Pötter and Azevedo (1974) analyzed four mangrove soil samples in salt plants of this plain, two of them had soils classified as poorly drained and the other two as very poorly drained. In the four samples, there was predominance of silt and clay fractions, in relation to sand, the granulometric composition of the fine earth reached $50 \%$ of clay and $46 \%$ of silt in the Dois Irmãos salt plant (LARACH; PÖTTER, AZEVEDO, 1974, p. 15).

The predominance of finer fraction sedimentation is due to the inexpressive flow of fresh water. In the saline area, the contribution of fluvial freshwater is almost null, since it disperses in the first few meters of the tangle of channels of the deltaic plain. The higher concentration of silt and clay is also due to the E-W position at the mouth of estuarine channels, as already explained, this geometric conformation of the coastline reduces the longitudinal transport of sediments and the silting of estuaries by moving dunes. The main source of sedimentation since the transgression of 5,000 years ago in this area that had been an old Holocene bay, must therefore have been marine clays, most of them are oceanic sediments, which explains the natural soil impermeability.

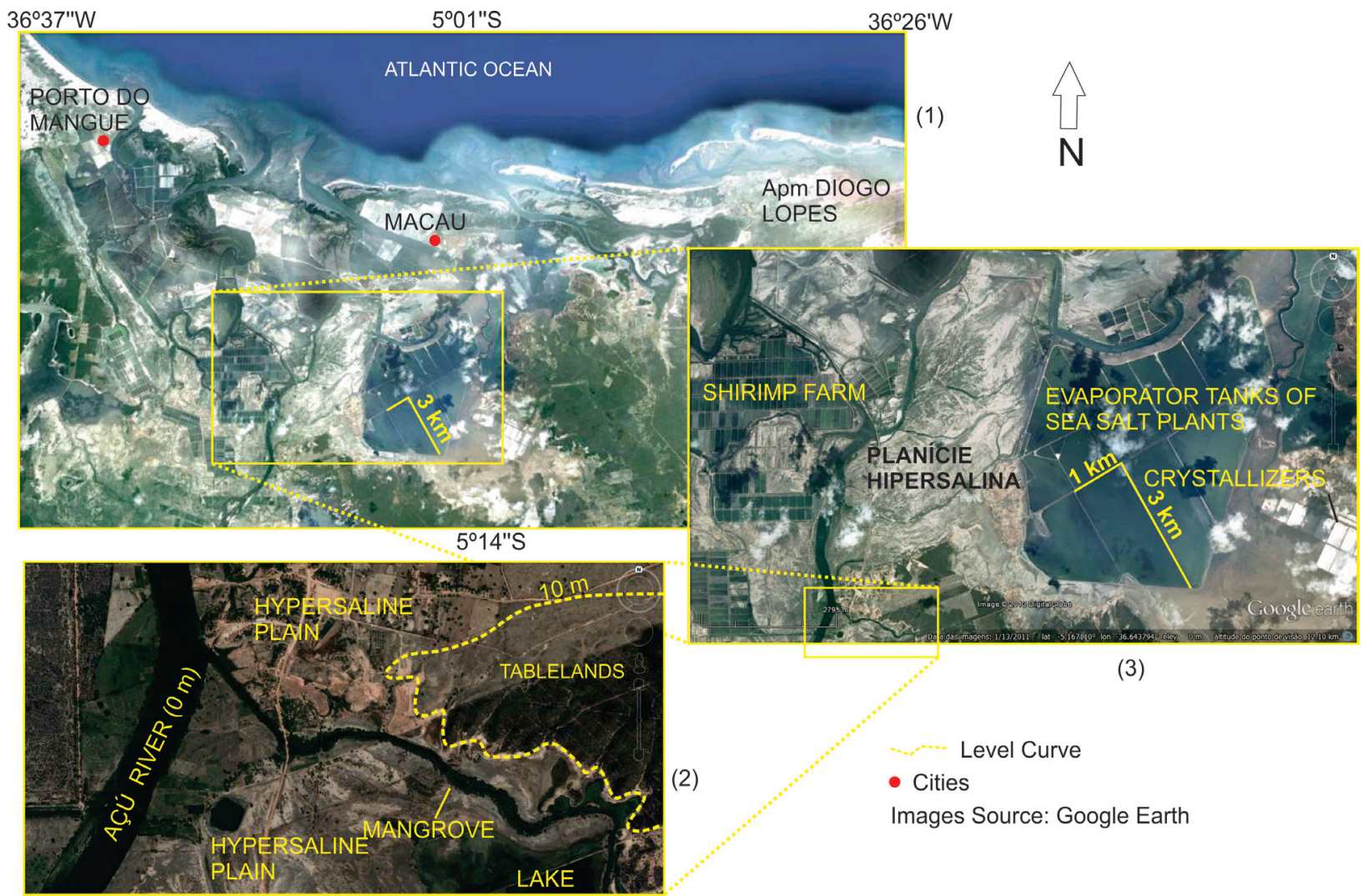

Figure 4 - Hypersaline plain of the Açu River. The large width of the area is highlighted (1); Açu River at altitudes of $0 \mathrm{~m}$ to more than $10 \mathrm{~km}$ from the mouth, narrow mangrove and broad hypersaline plain (2); Presence of saline evaporator tanks with $3 \mathrm{~km}$ x $1 \mathrm{~km}$ of dimension (3); There is a small tidal plain (Apm) in the district of Diogo

Lopes in Macau, where no salt production was recorded (1). Source: Google Earth, image of 01/13/2011.

The Delta of the Piranhas-Açu River has three estuarine channels called Conchas, Cavalos and Açu. The study by Silva, Miranda and Silva (2004) shows that in the Conchas channel, salinities 
from 40.90 to 44.77 grams of salt per kilogram of water were observed, increasing from the mouth to the continent, as well as in all other Estuaries studied by the authors, this channel presents little vertical stratification of salinity that tends to increase with the water confinement, as it moves away from the ocean, because in the Conchas channel, the fresh water contribution is almost null.

In the Cavalos Channel, the salinity is also high, ranging from 40.44 to 44.12 . The authors found a higher salinity concentration in stations 2 and 3, which are intermediate between the mouth and the freshwater source, which was also considered negligible.

In the Açu channel, the salinity was even higher, 40.65 to 50.79 . The lowest value was found at the mouth of the channel and the highest at an intermediate section between the mouth and the innermost sections (station 3), which is located upstream after a few meanders, which confirms our idea that the higher the water confinement, the higher the salinity, especially in the area with the greatest evaporation potential of the entire Brazilian coast, with 2,591.4 mm per year (INMET, 2009).

In general, in the three estuarine channels, salinity grows upstream up to about 5-7 km distant from the mouth when it starts to decrease, and can be classified as hypersaline.

Virtually all the natural factors point to the fluvial-marine plain of the Piranhas-Açu River as being the areas with the greatest potential for sea salt production in Brazil, based on the climatic aspects reported by Diniz (2013), through higher salinity rates, greater salt water confinement, and its greater extension, smaller slope and greater soil impermeability. The city of Macau, for example, is located on an island of the delta, therefore, in an extremely flat and easily flooded area in which in several places salt outcrops on the surface due to its high concentration

In many moments of history, this area was the largest sea salt producer of Brazil, currently, salt producing farms are in the municipalities of Macau and Porto do Mangue, where in 2011 about 1,400 thousand tons and 411 thousand tons of sea salt were produced, respectively (DNPM, 2012). Together with the production of the two municipalities, they accounted for about $40 \%$ of the total state production and $37.5 \%$ of the total national production.

Until the year of construction of the Areia Branca Port-Island, Macau was the largest national producer, so it claimed its own port; however, the greater political and economic strength of Mossoró influenced the numbers of sea salt production in state of Rio Grande do Norte.

\section{THE TIDAL PLAIN OF GALINHOS-GUAMARÉ}

The area of this plain is formed by a channel that enters the continent and is divided in other channels. In forming a flood tide delta, salt waters seasonally flood a vast area, the tidal plain occupies an area of $77.27 \mathrm{~km}^{2}$, belonging to the municipalities of Galinhos and Guamaré. The tidal channels, also called gamboas, carry oceanic waters inland and these are mixed with a small supply of fresh water of mainly phreatic origin, since the river drainage is reduced to small streams that are born very close to the ocean, in the low plateau of Serra Verde. This drainage can be characterized as ephemeral, the mixture of fresh and salt water is sufficient to create an estuarine environment, with the presence of mangroves, where salinity is close to that of the sea. This area also had hypersaline plains, but less expressive ones, which is due to the smaller confinement of salt water in relation to the other salt producing areas of Rio Grande do Norte.

Geologically, the context of this area is similar to that of the fluvial-marine plain of the Açu River, since both have undergone similar processes of formation in the last 5 thousand years, that is, this was also a recess area of the coastline when the last Holocnical transgression occurred. This area would be separated from the paleobay of the Açu River only by the Mangue Seco dome, which would be found in a context of sea level about 4 meters above the current one (BEZERRA; BARRETO; SUGUIO, 2003).

Caldas et al. (2006) have another interpretation for the evolution of the tidal plain, in a study carried out in the area, and concluded that the maximum elevation of the Holocene sea level that 
occurred about 5,900 years AP, was only $1.3 \mathrm{~m}$ above the maximum current syzygy tide and 2.9 $\mathrm{m}$ above the current mean sea level, which would be sufficient only for the formation of a lagoon located at the rear of barrier islands, which currently are united to the continent, forming the restinga forest. The interpretation described above is similar to that proposed by Lima (2004).

Figure 5 shows that, if there were no elevation of the Mangue Seco dome, the Galinhos-Guamaré tidal plain area would today be linked to the Açu River delta.

In the same figure, it is possible to observe that the coast between the Galinhos plains and the River Açu is extremely lowered in relation to its surroundings. This lowering is a reflection of the Carnaubais and Afonso Bezerra Fault systems (VALENTIM DA SILVA et al., 2007). The tidal plain of Galinhos is smaller than the fluvial-marine plains of the Mossoró and Açu Rivers, although it is much larger than the other salt producing areas in CSB, since it reaches $23 \mathrm{~km}$ in width and advances up to $6 \mathrm{~km}$ inland from the coastline.

In 2011, Galinhos produced 274 thousand tons of sea salt and Guamaré produced another 25 thousand tons of the product, which together account for $6.5 \%$ of the total state and $6 \%$ of the total national production for the same year (DNPM, 2012).

Through satellite images, Lima (2004) identified several sandwaves on the shallow platform adjacent to the Galinhos restinga forest, which testifies to the poor longitudinal transport of the area. This restinga forest is composed of sediments deposited by the wind action and longitudinal transport in the rear of three lines of beachrocks that are responsible for dissipating the energy and the erosive power of waves. The city of Galinhos is located on the restinga forest, close to one of the tips and in the rear of one of the beachrocks (or beach sandstones, or according to Lima [2004] beach reefs.

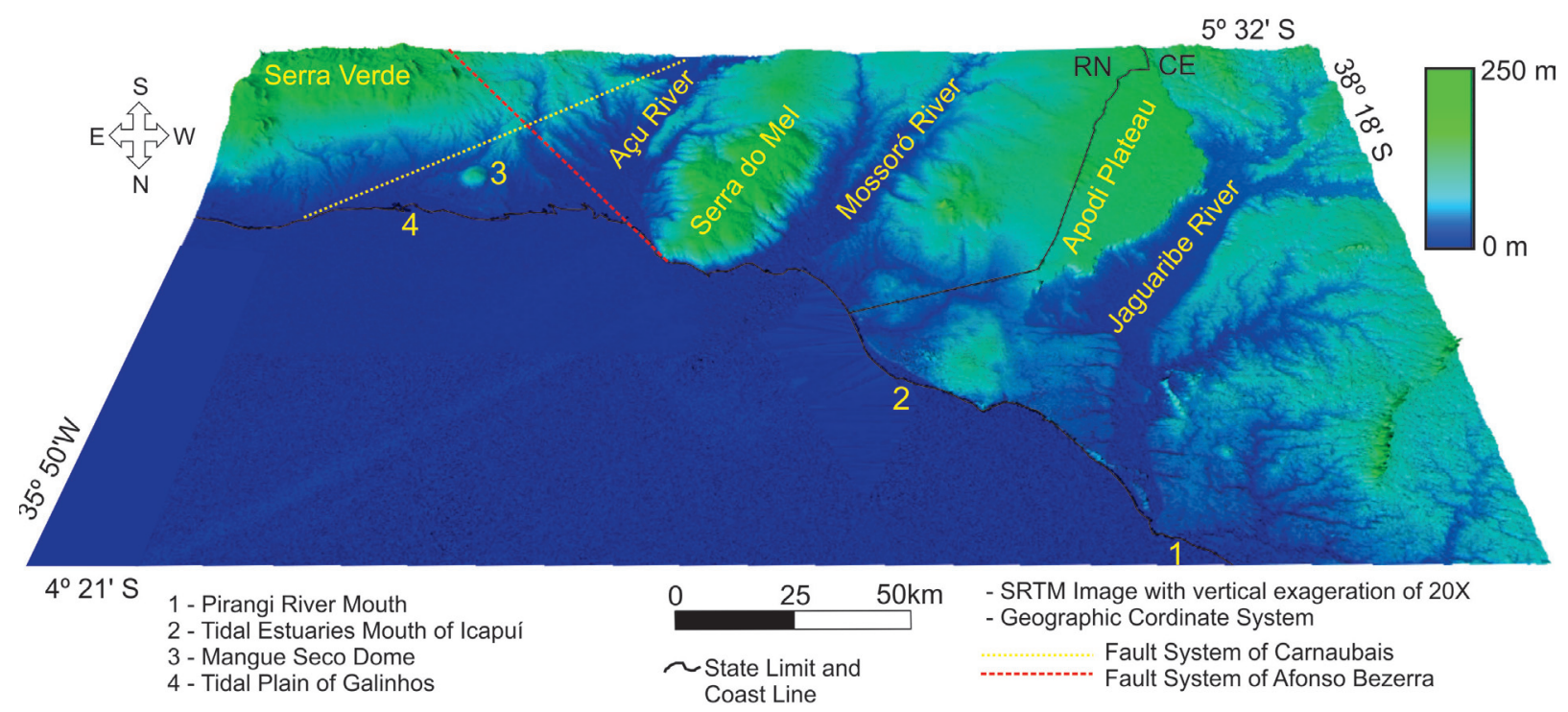

Figure 5 - Block 3D diagram of the Costa Branca (Costa do Sal) of the Brazilian Semiarid Coast. The figure highlights the fairly low coastline between the tidal plain of Galinhos and the fluvial-marine plain of the Açu River and the great advance of the quota $0 \mathrm{~m}$ inside the estuary of the Mossoró River.

The tidal plain of Galinhos has its current form conditioned by the role that the restinga forest plays in protecting the area from the erosive action of the ocean. The whole area of the plains is sedimentary, predominantly oceanic, since the river processes in the region are inexpressive. In the work of Costa Neto (2009), when sediment samples were collected in the tidal channels, the textural classes were identified: very coarse sand, coarse sand, medium sand, fine sand, very fine sand and silt, where coarser sands occur at the center of the tidal channels and finer ones at the margins, since only sediments transported by rolling and salting are deposited at the bottom of channels and in margins, sediments are transported in suspension due to the reduced stream speed. 
Caldas et al. (2006) analyzed lagoonal tidal sediments in the area and identified the occurrence of tidal flat deposits of dark green clay with a depth of $2.9 \mathrm{~m}$. The presence of organic matter with some shells and halite crystals was observed. These sediments are responsible for the soil impermeability, considering that the saline of Galinhos is positioned in a tidal plain. These clays should be similar to those that make up their soil.

Salinity measured by Silva, Miranda e Silva (2004) ranged from 41.19 to 46.75 in the tidal channels of Guamaré; and from 40.6 to 42.4 in Galinhos gamboas, with a tendency to increase from stations closer to the ocean to farther ones in both cases. The analysis of the data shows the inexpressive (almost non-existent) fluvial contribution to the system, and the tendency of salinity increase, as the confinement of oceanic waters in the continent increases, being able to be classified as hypersaline.

In Galinhos, the presence of mangroves is much more striking than in estuaries of the Mossoró and Açu Rivers, because in this area, the salinity does not exceed 42 grams of salt per kilogram of water. The existing saline in the area was installed in the early 1980s in the mangrove area.

According to Costa Neto (2009), sea salt producing areas of Rio Grande do Norte are of "inverse estuaries" or "negative", since salinity increases upstream, which is due to the strong deficit between the contribution of freshwater and the high rates of evaporation of the area. The estuary of the Jaguaribe River could be included in the same classification.

The tidal plain of Galinhos-Guamaré is another area of great potential for sea salt production, the third most important in Brazil. The only limitations to saline activity are the size of the area in relation to the plains of Mossoró and Açu Rivers, the greater presence of mangrove in the plain and its distance from the Areia Branca Port-Island, the transportation by land is also a little more difficult than in other areas, since sea salt plants are located on tidal plain islands.

\section{FINAL CONSIDERATIONS}

In this work, the conditions that provide the great productivity to saline companies in the Costa do Sal and surroundings, especially in the state Rio Grande do Norte, were analyzed. Empirically, sea salt producers in Brazil have realized the great productive potential of this area of the Brazilian coast, which has the largest sea salt companies that have supply most of the national consumption of salt for decades.

In addition to the climatic factors, which are very similar in all the analyzed areas, the determinants of sea salt production are linked to soil permeability, sediment deposition of silt and clay fractions, longitudinal sediment transport along the coastline, sedimentation of estuaries by moving dunes, the slope of plains, the size of areas flooded by tides and the natural salinity of confined waters.

In the fluvial-marine plain of the Pirangi River, the main limitation to the saline activity is due to its small area, which makes the development of a mechanized saline industry difficult. The largest current vocation in the area is for shrimp farming using smaller tanks.

The fluvial-marine plain of the Jaguaribe River presents unfavorable conditions for sea salt production, among them being very narrow, having very permeable soils and presenting good flow of fresh water to the estuary, especially in above-average rainy years.

The tidal plain of the Icapuí River has its greatest potential for sea salt production in soil impermeability and ease of production runoff. Its major limitation is its small flood area, yet it is the main salt producer in the state of Ceará.

The fluvial-marine plain of the Apodi-Mossoró River produces about $49 \%$ of the national salt, being the most important in Brazil. Its high productivity is due to the dry climate, soil impermeability, its extremely smooth slope and the magnitude of its flooded area. In addition to these factors, the activity gained momentum with the construction of the Areia Branca Port-Island. 
The fluvial-marine plain of the Piranhas-Açu River presents better conditions for sea salt production than the fluvial-marine plain of the Apodi-Mossoró River. It has high salinity of confined waters, smaller declivity, greater extension and greater soil impermeability. This area was once the largest sea salt producer of Brazil, currently producing about $37.5 \%$ of the national total. The fact that it caused production stagnation while the neighboring plain (Apodi-Mossoró) continued to grow is due to the fact that the Port-Island built in Areia Branca in is more distant from this plain than to Apodi-Mossoró, impairing production runoff.

The tidal plain of Galinhos-Guamaré presents great potential for sea salt production, being the third most important of Brazil, with similar conditions to neighboring areas. The limiting factors are the smaller area extension, greater presence of mangroves in the plain and its greater distance to the Areia Branca Port-Island.

After analyzing these areas, it was found that the fluvial-marine plains of the Apodi-Mossoró and Piranhas-Açu Rivers and the tidal plain of Galinhos-Guamaré are those with the greatest potential for sea salt production. In these areas: soils are less permeable; the longitudinal transport of sediments and the silting of estuaries by moving dunes are lower; the water salinity is higher; and the sediment deposition of the silt and clay fractions is higher.

It could be concluded that the confinement of tidal water in the continent is a determining factor in the productive potential of fluvial-marine or tide plains. In turn, the greater or lesser confinement power of marine water is linked to three factors: continental freshwater flow; the slope of the plain and the geomorphological characteristics of the width and length of areas flooded by tides. This set of factors causes the confinement to be translated into natural variations of salinity that also determine the salt productivity capacity of these plains.

\section{BIBLIOGRAPHIC REFERENCES}

AB'SÁBER, A. N. Problemática da desertificação e da savanização no Brasil intertropical. Coleção Geomorfologia, São Paulo v. 53, p. 1- 19, 1977.

ANA. AGÊNCIA NACIONAL DE ÁGUAS. Atlas Nordeste - Abastecimento urbano de água: Alternativas de oferta de água para as sedes municipais da região nordeste do Brasil e do norte de Minas Gerais. Superintendência de planejamento e Recursos hídricos. Brasília/DF, 2006. 82p. disponível em: <www.ana.gov. br/bibliotecavirtual/arquivos/atlas.pdf>. Acesso em: 05 jun. 2013

BEZERRA, F. H. R. ; BARRETO, A. M. F. ; SUGUIO, K. . Holocene sea-level history on the Rio Grande do Norte State coast, Brazil. Marine Geology, Holanda, v. 196, n.1-2, p. 73-89, 2003.

BEZERRA, F. H. R.; LIMA FILHO, F. P.; AMARAL R. F.; CALDAS, L. H. O.; COSTA NETO, L. X. Using beachrock and hydro-isostatic predictions to identify Holocene coastal tectonics in NE Brazil. In: Geol. Soc., London, Special Publication. (Org.). Coastal Tectonics. Stewart, I. and Vita-Finzi, C. (eds.). 146 ed.Londres: Geological Society, 1998, v. 146, p. 279-293.

BORBA, A. L. S. Estudos sedimentológicos, morfodinâmicos e da vulnerabilidade das praias da piedade, candeias e barra das jangadas - município do Jaboatão dos Guararapes-PE. Recife, 1999. 146f. Dissertação (Mestrado em Geociências). Programa de Pós-Graduação em Geociências, Universidade Federal de Pernambuco, Recife, 1999.

CALDAS, L. H. O. Estudo geológico e geofísico da falha de Carnaubais, Bacia Potiguar - RN, e implicações neotectônicas. Natal, 1998. 88 f. Dissertação (Mestrado em Geodinâmica e Geofísica). Programa de Pós-Graduação em Geodinâmica e Geofísica, Universidade Federal do Rio Grande do Norte, Natal, 1998.

CALDAS, L. H. O.; OLIVEIRA JÚNIOR, J. G.; MEDEIROS, W. E.; STATTEGGER, K.; VITAL, H. Geometry and evolution of Holocene transgressive and regressive barrier on semi-arid coast, NE Brazil. . Geo-Marine Letters, Amsterdam, 2006.

CARVALHO, M. S. B. de S.; SOUZA, M. J. de; FREITAS FILHO, M. R. de; SOARES, A. M. L. Caracterização do uso e ocupação do estuário e entorno do rio Pirangi (CE). In: SIMPÓSIO BRASILEIRO DE 
SENSORIAMENTO REMOTO, 11., 2003, Belo Horizonte, Anais... Belo Horizonte: DPI/INPE, 2003. Disponível em: $<$ http://marte.dpi.inpe.br/col/ltid.inpe.br/sbsr/2002/11.14.12.57.53/doc/13_173.pdf >. Acesso em: 08 maio 2013.

CARVALHO NETA, M. de L. Evolução geomorfológica atual e análise ambiental da foz do rio Jaguaribe, Ceará. Fortaleza, 2007. 126f. Dissertação (Mestrado em Geografia). Programa de Pós-Graduação em Geografia, Universidade Federal do Ceará, Fortaleza, 2007.

CAVALCANTE, A. A. Aspectos da produção de sedimentos e seus efeitos na Gestão dos recursos hídricos no Baixo Vale do rio Jaguaribe - CE. Fortaleza, 2001. Dissertação (Mestrado em Geografia). Mestrado Acadêmico em Geografia, Universidade Estadual do Ceará, Fortaleza, 2001.

CBH-PIANCÓ-PIRANHAS-AÇÚ. Comitê da bacia Hidrográfica do Rio Piancó-Piranhas-Açú. A bacia. Disponível em: <http://www.cbhpiancopiranhasacu.org.br/site/a-bacia/>. Acesso em: 05 jun. 2013.

COSTA, D. F. S.; Silva, A. A. ; Medeiros, D. H. M. ; LUCENA FILHO, M.A. ; DE MEDEIROS ROCHA, R. ; LILLEBO, A. I. ; SOARE, A. M. . Breve revisão sobre a evolução histórica da atividade salineira no estado do Rio Grande do Norte (Brasil). Sociedade \& Natureza (UFU. Online) v. 25, p. 24-34, 2013.

COSTA NETO, L. X. Caracterização geológica, geomorfológica e oceanográfica do sistema Pisa Sal, Galinhos/RN - Nordeste do Brasil, com ênfase à erosão, ao transporte e à sedimentação. 2009. $291 \mathrm{p}$. Tese (Doutorado em Geodinâmica e Geofísica). Universidade Federal do Rio Grande do Norte, Natal-RN, 2009. DIAS, F. J. da S. Hidrodinâmica das descargas fluviais para o estuário do rio Jaguaribe (CE). Fortaleza, 2007. 112f. Dissertação (Mestrado em Ciências Marinhas Tropicais). Instituto de Ciências do Mar. Programa de Pós-Graduação em Ciências Marinhas Tropicais, Universidade Federal do Ceará, Fortaleza, 2007.

DINIZ, M. T. M. Condicionantes socioeconômicos e naturais para a produção de sal marinho no Brasil: as particularidades da principal região produtora. Fortaleza, 2013. 227f. Tese (Doutorado em Geografia). Programa de Pós-Graduação em Geografia, Universidade Estadual do Ceará, Fortaleza, 2013.

DINIZ, M. T. M.; OLIVEIRA, G. P. Proposta de compartimentação em mesoescala para o litoral do Nordeste Brasileiro. Revista Brasileira de Geomorfologia, v. 17, n. 3, p. 565-590, 2016.

DNPM. Depto. Nacional de Produção Mineral. Sumário Mineral 2012. Brasília: DNPM/DIPLAM, 2012. DNPM. Depto. Nacional de Produção Mineral. Sumário Mineral 2015. Brasília: DNPM/DIPLAM, 2015. FUNCEME. Fundação Cearense de Meteorologia e Recursos Hídricos; UECE. Universidade Estadual do Ceará. Avaliação do uso potencial de áreas estuarinas a partir da identificação e caracterização do comportamento de variáveis hidro-climáticas, oceanográficas e ambientais - estudos de caso: rio Pirangi-CE. Fortaleza: FUNCEME, 2007. Disponível em: <http://msg.funceme.br:8082/funceme/projetos-1/ projetos-concluidos/projeto-pirangi/Pirangi.pdf/at_download/file> . Acesso em: 08 maio 2013.

GODOY, M. D. P. Mudanças na sedimentação do estuário do rio Jaguaribe (CE) devido a mudanças nos usos do solo. Fortaleza, 2011. 131f. Dissertação (Mestrado em Ciências Marinhas Tropicais). Instituto de Ciências do Mar, Programa de Pós-Graduação em Ciências Marinhas Tropicais, Universidade Federal do Ceará, Fortaleza, 2011.

IBGE. Instituto Brasileiro de Geografia e Estatística. Diagnóstico ambiental da bacia do rio Jaguaribe: Diretrizes gerais para a ordenação territorial. Salvador: IBGE, 1999. Luiz Carlos Soares Gatto (supervisor).

INMET. Instituto Nacional de Meteorologia. Normais Climatológicas do Brasil 1961-1990. Organizadores: Andrea Malheiros Ramos, Luiz André Rodrigues dos Santos, Lauro Tadeu Guimarães Fortes. Brasília, DF: INMET, 2009.

LARACH, J. O.; PÖTTER, R. O.; AZEVEDO, F. D. de. Investigações generalizadas sobre solos e fatores que influenciaram a produção salineira dos estados do Rio Grande do Norte e Ceará. Rio de Janeiro: Ministério da Indústria e do Comércio. Comissão Executiva do sal, 1974.

LIMA, Z. M. C. Caracterização da dinâmica ambiental da região costeira do município de Galinhos, litoral setentrional do Rio Grande do Norte. 2004. 157 p. Tese (Doutorado em Geodinâmica e Geofísica). Universidade Federal do Rio Grande do Norte, Natal-RN, 2004.

MACHADO, G. M. V. Análise morfo-sedimentar da praia, antepraia e plataforma continental interna da linha de costa do Parque Nacional de Jurubatiba- RJ. Rio de Janeiro, 2007. 170f. Dissertação (Mes- 
trado em Geografia). Programa de Pós-Graduação em Geografia, Universidade Federal do Rio de Janeiro, Rio de Janeiro, 2007.

MAIA, L. P. Controle tectônico e evolução geológica sedimentológica da região da desembocadura do rio Jaguaribe - CE. Recife, 1993. 144f. Dissertação (Mestrado em Geociências). Programa de Pós-Graduação em Geociências, Universidade Federal de Pernambuco, Recife, 1993.

MAIA, L. P. Procesos Costeiros y Balance Sedimentario ao lo Largo de Fortaleza (NE-Brasil): Implicaciones para una gestión adecuada de la zona litoral. Barcelona, 1998. 269 f. Tese (Doutorado em Ciências Del Mar), Facultat de Geologia - Universitat de Barcelona, Dep. D’Estratigrafia y Paleontologia, Barcelona, Espanha, 1998.

MAIA, R. P. Geomorfologia e neotectônica no vale do rio Apodi-Mossoró RN. Natal, 2012. 218f. Tese (Doutorado em Geodinâmica). Programa de Pós-Graduação em Geodinâmica e Geofísica, Universidade Federal do Rio Grande do Norte, Natal, 2012.

MAIA, R. P.; BEZERRA, F. H. R. Tectônica pós-miocênica e controle estrutural de drenagem no rio Apodi-Mossoró, Nordeste do Brasil. Boletim de Geografia (Online), v. 31, p. 57-68, 2013.

MAIA, R. P.; CLAUDINO-SALES; V.; PEULVAST, J. P. Evolução morfoestrutural dos compartimentos do relevo do baixo Jaguaribe - Ceará. In: SIMPÓSIO NACIONAL DE GEOMORFOLOGIA, 6., 2006, Goiânia, Anais eletrônicos... Goiânia: UGB, 2006. Disponível em: <http://www.labogef.iesa.ufg.br/links/ sinageo/articles/074.pdf $>$. Acesso em: 08 maio 2013.

MARINS, R. V.; LACERDA, L. D. de; ABREU, I. M.; DIAS, F. J. da S. Efeitos da açudagem no rio Jaguaribe. Ciência Hoje. V. 33, n. 197, p. 66-70, set. 2003.

MEIRELES, A. J. A.; RAVENTOS, J. S.; THIERS, P R. L. Aspectos geodinâmicos do delta de maré da planície costeira de Icapuí/CE. In: SILVA, J. B. da; DANTAS, E. W. C.; ZANELLA, M. E.; MEIRELES, A. J. de A. (orgs.). Litoral e Sertão, natureza e sociedade no nordeste brasileiro. Fortaleza: Expressão Gráfica, 2006.

MEIRELES, A. J. A.; SANTOS, A. M. F. dos. Evolução geomorfológica da planície costeira de Icapuí, extremo leste do Ceará, Nordeste do Brasil. Geografia (Rio Claro. Impresso), v. 36, p. 519-534, 2011.

MOURA-LIMA, E.N. ; SOUSA, M. O. L. ; BEZERRA, F. H. R. ; CASTRO, David L. ; DAMASCENA, R.V.C.; VIEIRA, M. M. ; LEGRAND, J. M. Reativação Cenozóica do Sistema de Falhas de Afonso Bezerra, Bacia Potiguar. Geociências (São Paulo. Online), v. 30, p. 77-93, 2011.

MUEHE, D. O litoral Brasileiro e sua Compartimentação. In: CUNHA, S. B., GUERRA, A. J. T. (orgs.). Geomorfologia do Brasil. $4^{\text {a }}$ Ed. Rio de Janeiro: Bertrand Brasil, 2006.

MUEHE, D. Geomorfologia Costeira. In: Guerra, A. J. T.; CUNHA, S. B (Orgs) Geomorfologia: uma atualização de bases e conceitos. 8. ed. Rio de Janeiro: Bertrand Brasil, 2008. p. 253-308.

PEULVAST, J. P. CLAUDINO SALES, V. Reconstruindo a evolução de uma margem continental passiva: um estudo morfogenético do Nordeste brasileiro. In: SILVA, J. B; LIMA, L. C; ELIAS, D. (Org.). Panorama da geografia brasileira 1. São Paulo: Annablume, 2006. 277-318p.

SEMACE. Superintendência Estadual do Meio Ambiente do Ceará. Demonstrativo das ações de ordenamento, controle e monitoramento ambiental da atividade de carcinicultura no estado do Ceará. Fortaleza: SEMACE/SOMA, 2004.

SEMARH/RN. Secretaria de Estado de Meio Ambiente e dos Recursos Hídricos do Rio Grande do Norte. Plano Estadual de Recursos Hídricos: Relatório Síntese. SERHID, 1998. Disponível em: <http://www. semarh.rn.gov.br/contentproducao/aplicacao/semarh/legislacao/gerados/dowloaddoplano.asp $>$. Acesso em: 17 maio 2013.

SILVA, C. A. R.; MIRANDA, L. B.; SILVA, G. de O. Caracterização física, físico-química e química dos estuários Apodi, Conchas, Cavalos, Açu, Guamaré, Galinhos, Ceará-Mirim, Potengi, Papeba e Guaraíra. RELATÓRIO FINAL: Físico-Química Marinha (Litoral Setentrional). Universidade Federal do Rio Grande do Norte, Natal, 2004.

SOUZA, M. J. N. de. Bases Naturais e Esboço do Zoneamento Geoambiental do Estado do Ceará. In: LIMA, L. C., SOUZA, M. J. N. de, MORAIS, J. O. de. Compartimentação Territorial e Gestão Regional do Ceará. Fortaleza: FUNECE, 2000. 
SUGUiO, K.; MARTIN, L.; BITTENCOURT, A. C. S. P.; DOMINGUES, J. M. L.; FLEXOR, J.-M.; AZEVEDO, A. E. G. Flutuações do nível relativo do mar durante o Quaternário superior ao longo do litoral brasileiro e suas implicações na sedimentação costeira. Revista Brasileira de Geociências, v. 15, 1985.

VALENTIM DA SILVA, D. R.; AMARO, V. E.; SOUTO, M. V. S.; PEREIRA, B. R. B.; SOUZA, D. S.; SOUZA, A. S. Imagens SRTM aplicadas à análise do comportamento morfo-tectônico da paisagem, como auxílio ao monitoramento ambiental no litoral setentrional do Rio Grande do Norte. In: 4 Congresso Brasileiro de P\&D em Petróleo e Gás, 2007, Campinas-SP. Anais..., 2007. 